\title{
Decison - Making in the Curriculum Development Process in Higher Education in Kosovo - Case of "Haxhi Zeka" University
}

\author{
Prof. Dr. Justina Shiroka- Pula \\ University of Prishtina "Hasan Prishtina", Republic of Kosovo, justina.pula@uni-pr.edu
}

Prof. Ass. Dr. But Dedaj

University of Prishtina "Hasan Prishtina", Republic of Kosovo, but.dedaj@uni-pr.edu

MSc. Luljeta Aliu

WUS Kosova, Republic of Kosovo, aliu.lule@gmail.com

\section{Doi:10.5901/ajis.2014.v3n2p197}

Abstract

One of the most important challenges of the higher education sector in Kosovo, in Europe and elsewhere, is the development and updating of the curricula (study programs), which is consistent with the needs of labour market, comparable with the similar universities abroad, along with Bologna Declaration and with recent trends in European higher education. The aim of this study is to analyse system of higher education in Kosovo: legal framework and managerial accountability of the public and private higher education institutions in the process of curriculum development (study programs), and the case study regarding to the curriculum development is conducted at University "Haxhi Zeka" in Peja. The study is developed based on two main research methods: 1) Survey method, and 2) Roundtable discussion. In addition, a great importance is dedicated to the research, analysis, use of national and international strategic documents that consequently, administrate the process of curriculum development, respectively the higher education in Kosovo. The survey results shows that, decision-making process on curricula development undergo through different levels at public higher education institutions comparing with private ones. Further, curriculum of University "Haxhi Zeka" is developed based on market researches and is consistent with the labour market needs.

Keywords: Higher Education, Curriculum development, Higher education reforms, Competences, Labour market needs.

\section{Introduction}

Usually, in developing countries most of the institutions of higher education are being confronted with an increasing distance between study programs (curriculum) offered, as with the requirements of the society, business and industry, for more flexible workforce and competent in contemporary developments.

In this regard, the study analyses the Higher education system, legal framework and managerial responsibility at public and private higher education providers. While the case study concludes if the current curricula of University "Haxhi Zeka", is consistent with the labour market needs; who initiates the modification and updating of study programs; how do students and employers appraise the current curriculum of the University, and what competencies do students benefit after graduation. In the last part of the study, a general analysis of the results from the research will be given, that lead to concluding remarks with concrete implications and recommendations for decision making on curriculum development for new study programs and revision of curricula in the Higher Education Institutions in Kosova, especially at University "Haxhi Zeka".

\section{Management and Decision- Making at Higher Education Institutions}

Practices of the managing by quality are not something new in the higher education. Recently, literature has documented the value of higher education through experiences that have practices Tuttle philosophy (Maguad and Krone, 2011), where according to him: universities and colleges are facing with a constantly increasing pressure as a result of internal and external factors. The environment is drastically changing, while the managerial structure in higher education and 
culture hardly changes. In this aspect, universities and colleges are choosing quality for increasing, in order to be the choice of industry and government.

The existing managerial system is out of date and cannot ensure success in the competitive and growing market. Furthermore, recently published reports shows that, the report between government and higher education institutions by the so-called "state-supervising-model", are substituting the old system "state-controlling-model" in the context of scientific researches, and not seen any more as isolating institutions.

\section{Model of organization and decision-making in higher education in Kosovo}

The role of the state as key factor for development of higher education in Republic of Kosovo, as in other countries is regulated by law. The objectives of higher education are:

- creation, development, protection and transmission of knowledge through teaching and scientific and research works;

- preparation of students for further studies, professional practice and lifelong learning through the acquisition and depth development knowledge and high level competences;

- offering opportunities for all inhabitants of Kosovo who are able to benefit from such education and to contribute to their society and country, throughout their lives. (Law on Higher Education Nr. 04/L-037, 2011).

Additionally, higher education in Kosovo is organized, as following:

- first level - three (3) to four (4) years of studies by which the student reaches 180, respectively 240 /ECTS/, and obtains Bachelor Diploma.

- $\quad$ second level - one (1) to two (2) years of studies after completion of the first level by which the students reaches 60, respectively 120/ECTS/ and the student obtains Master Diploma.

- $\quad$ third level - program of doctorate studies with academic and independent research scientific character.

- $\quad$ any other post-secondary education in the levels 5, 6, 7 and 8 of the European Qualifications Framework for Lifelong Learning, for which credits may be given (ECTS) (Law on Higher Education Nr. 04/L-037, 2011).

As regard to the hierarchy of reporting and decision-making, $\mathrm{HE}$ is governed and function as it is illustrated in the figure below:

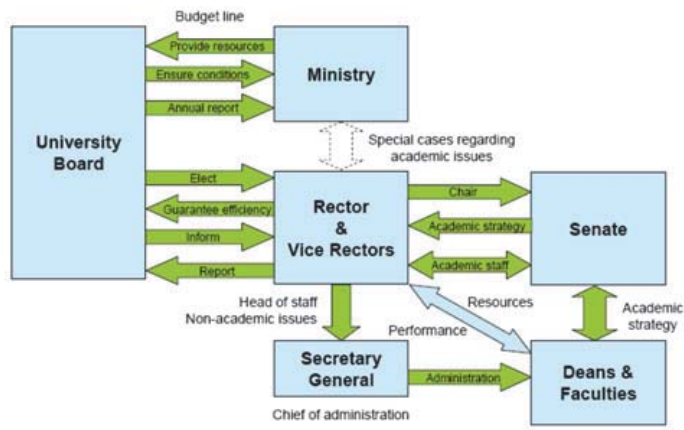

Figure 1. Organisation of public HE institutions in Kosovo (Statute of the University of Prishtina, 2007)

As it is presented above, all higher education institutions: public and private, are inter- related and reports to government, respectively MESTK.

\section{MEST Policies for the Curriculum Development in Higher Education in Kosovo}

Developed and published documents by MEST offers clear suggestions for the institutions of Higher Education in Kosovo, for conditions and criteria that they have to meet on the developing new programs, or on updating the current ones. According to the MEST, study programs have to be clear, readable, measurable, and comparable and as so, the intention is to facilitate on the evaluating and accreditation process. (RobertM.Krone, 2012)

In addition, also the main strategic documents for higher education in Kosovo identify the curriculum development as one of the main challenges of this sector and also as one of the target objective. According the "Strategic Plan for High 
Education in Kosovo, 2011-2016, study programs of private or public institutions of Higher Education should reflect the needs of labour market and increase the employment of graduates, by promoting the technology transfer, innovation, and entrepreneurship.

\section{Decision-making in the process of curriculum development at public HEl in Kosovo}

Immediately after the war, higher education system made efforts to start with changes, by having the main objective to fully integrate in the European Higher Education Area. It still remains as objective to strictly fulfil one of the criteria of the Bologna Process. In this case, in response to changes and fulfilment of objectives, higher education institutions (only UP at that time) began the implementation of the Bologna process, in the academic year 2001/2002, when there were significant efforts at the University of Pristina for substantial reform of the curriculum and changes on the duration of study according to Bologna system. At that time, the process was organized with a top-down approach, without the involvement of teachers in the status quo analysis, the assessment of needs and the planning process, but only by implementing the designed curricula according to Bologna objectives. On the other hand, private institutions of higher education have developed curricula primarily based in University of Prishtina- UP curricula, and in some cases based on the curricula of countries in the region and beyond. In this sense, the exception makes the American University of Kosovo, which is based on the American study system (MESTK, 2007).

The UP, as the only public HE institution in Kosovo until 2010, with decision by the Assembly of Kosovo, the second public institution of higher education in Kosovo, the University of Prizren "Ukshin Hoti" was established. Then in 2011 the University of Peja "Haxhi Zeka" who is a descendant of the Faculty of Applied Science in Business (FSHAB), continuing with the opening of other public universities in 2013: University of Gjilan "Kadri Zeka", Mitrovica University and University Gjakova "Fehmi Agani".

\subsection{Development of study programs (curricula) and decision-making}

Development of study programs at public universities is regulated by the statute of the university, as well as the management and functioning of the university. Proposal for new study programs, adaptation and modification of existing programs is undertaken by the Commission in each academic study. Besides these, the study commission is also responsible for: developing concepts assess and comment requirements - in order to prepare the reports which are determined in the Senate or the Council of the respective unit. In addition, study commissions at the University of Prishtina "Hasan Prishtina" has the following composition:

1. Vice-rector or Dean for teaching (chair);

2. Five professors;

3. An assistant;

4. Two students with a GPA at least eight. (Statute of the University of Prishtina, 2011).

While in other public universities: University of Prizren "Ukshin Hoti" and University "Haxhi Zeka" in Peja, number of members varies by professors and students comparing with the University of Prishtina "Hasan Prishtina".

\section{Decision-making in the process of curriculum development at private HEl's}

The existence and operation of private higher education providers ${ }^{1}$ was originally initiated with the approval of the Law on Higher Education in Republic of Kosovo. This law was developed based on the latest developments of the European system of higher education, and in particular to achieve the goals set by the Bologna process.

\subsection{Development of study programs (curricula) and decision-making}

Management and decision-making processes of the Private HE providers varies from institution to institution and there is no unique document except the law on higher education and the demands of the Kosovo Accreditation Agency, which defines and regulates the development of academic programs. In order to acquire information from relevant documents

\footnotetext{
${ }^{1}$ Institution established for profit or non profit from any person, group of persons or organization other than the Government of the Republic of Kosovo or any other sovereign state (Law on Higher Education Nr. 04/L-037, 2011), 2.
} 
are checked several web sites of the accredited private HE providers (Illyria College, FAMA College, UBT College, AAB College) and not found any document/ statute which is public. Therefore, in order to understand more clearly the development and decision-making process for study programs is seen as needs to conduct researches at private $\mathrm{HE}$ providers in Kosovo. A questionnaire was developed and sent to 10 private higher education institutions-HEl's which are accredited by KAA. The received data from 10 respondents are collected and analysed.

\subsection{Results analysis}

Based on the results of the research, all the respondents answered that they have internal procedures for reviewing/ modifying study program. Thus, in the question:" if they conduct researches for the labour market needs prior to development new study programs?", they answered that they do so. This can be seen as an interconnected process , because, as private institutions have done research regarding the market needs, therefore take steps in the development of procedures for curriculum revision. On the other hand, in the context of the management and decision-making in the question: "Who is responsible for developing study programs (curricula), revision of existing and initiating new study programs?", The majority of respondents (45.45\%) of responded that, this responsibility belongs to the Deans of faculties. Some institutions (27.27\%) answered that the Rector is responsible to do so, and also the same percentage (27.27\%) responded that the development of new study programs is undertaken by the professors' team. Depending on the internal organization of the institution, there were also other comments that apart from the above mentioned, responsible for the curriculum development are: academic policy committee, business community, the working group for market research and science council. Always in the context of decision making, the question: "Who takes the decision on approval of new programs before they are sent to Kosovo Accreditation Agency?", in the majority of institutions (40.00\%), the decision is taken by: Academic Council or the so-called Scientific Council, followed by the Senate (30.00\%) and smaller number of institutions have involved the management - Board of directors (20.00\%) and Rector (10.00\%). Consequently, it is clearly understood that there are no similar practices and has a relatively high diversity about how are regulated and how private higher education providers develop and make decisions for the offered study programs. This is also the clear indication that this depends solely on institutional organization and not by regulations or best practices.

\section{Case Study- Curriculum development at University "Haxhi Zeka"}

The "Haxhi Zeka" Public University, the descendant of the Faculty of Applied Sciences in Business (FSHAB) in Peja, which was established in 1960, although established in 2011, is dedicated to continuously revise its study programs (curriculum), so that they have adaptability to the needs of Kosovo society, economy, trends in higher education and the world economy. As regard to the development of the study programs, like in other public institutions, development of new study programs and/or modification of the existing programs, are initiated by the study commissions within the academic units, which commission is composed by:

1. Vice rector or vice dean for teaching (chair);

2. Three professors;

3. One teaching assistant;

4. One student, with GPA at least 8 (Statute of University "Haxhi Zeka", 2011).

Consequently, the decision - making on curriculum development passes through a process, where with the approval by the study commission, the program have to be approved by the academic unit council, then the final approval prior to be submitted at Kosovo Accreditation Agency, it has to be approved by the senate of the university. Therefore, relying on the purpose of the report below are described the results analysis.

\subsection{Methodology}

Firstly, three different questionnaires were designed, as to obtain the necessary information from three targeted groups: academic staff, students and different companies, which are conducting certain activity in the region of Peja and beyond. The three target groups are considered to be stakeholders in the development of the study programs in UHZ. Selection of these groups is based on purpose, to obtain as much as possible different perspectives of the actors, involved in research, which in a way affect the process of curriculum development in UHZ. After the questionnaires development, their distribution, data collection, data processing and analysis have been distributed to the target groups. In the survey 92 respondents have participated: from which, 39 were professors, 49 students and 4 representatives of certain 
companies.

\subsection{Roundtable}

Beside questionnaires and the survey realized with stakeholders, a round table discussions with professors and students of the University "Haxhi Zeka" as well as with the company representatives was organized. During these meetings they had discussed some of the results of the survey, adding to his their attitudes and opinions on the importance of development or revision of curriculum in $\mathrm{UHZ}$, according to the needs and requirements of the labour market, always in correspondence with trends in higher education in Kosovo. Additionally, conclusions emerged from the round table discussions are also included in the report.

\subsection{The Result Analysis}

Results emerged from the conducted research show that target groups concerned, as a part of research; academic staff of UHZ, companies and students, have a solid knowledge about curriculum that is provided in the Faculty of Agribusiness in UHZ. For a clearer illustration, the answers are shown in a graphic form. As shown, the results of three target groups; students, academic staff, and the companies representatives, are crossed with one another as to compare the results of all three respondent groups, meantime by increasing the analysing level, for a final purpose to reflect the situation as objectively as possible. In the following section, the analyses of the results and findings that emerged from questionnaires are presented.

\section{Figure 2.}

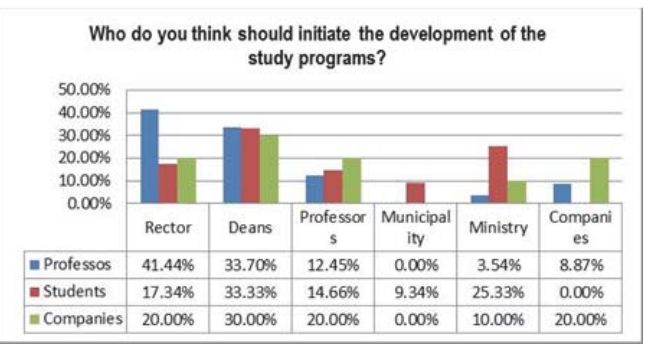

In the question: Who do you think should initiate the development of new study programs, responses revealed from teachers and students have great similarities, compared to the responses given by representatives of the companies. Accurately, $41.4 \%$ of academic staff of UHZ considered that the rector initiates the process of a new curriculum development and $33.7 \%$ noted that this depends on deans. According to the professors, only $8.8 \%$ of importance relies on enterprise. On the other hand, students consider the rector's influence is about $17.3 \%$, whereas the dean's influence is $33.3 \%$. They also referred that, the impact of enterprises is $0.0 \%$ and $9 \%$ on Municipalities initiating programs is considered. While $20 \%$ of company representatives noted that the rector should be initiating new programs development, $30 \%$ of them said that deans are the one supposed to initiative, $20 \%$ said professors and $20 \%$ agreed in companies' importance. As a result there emerged two main tendencies that opposed to each other. The concepts of students and professors on initiation programs development corresponds better with the maxim that economic section (in this case represented by companies) should not be involved in the process of development.

Figure 3.

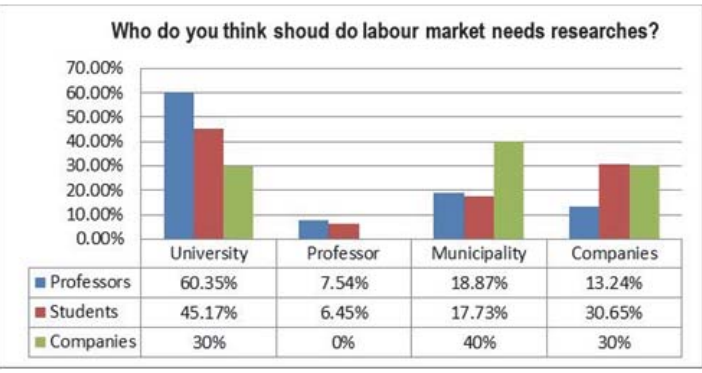


Further professors and students share the same opinion on the importance of labour market needs research, but in the question, who is supposed to do such a research, respondents gave various answers. As far as professors are concerned, $60.3 \%$ of them stated that University should take the responsibility on conducting the researches, $18.8 \%$ stressed that Municipality should do it, $13.2 \%$ are given to entrepreneurs and $7.5 \%$ themselves, respectively to the professors. Whereas $45.1 \%$ of students consider that the research should be done by University, $17.7 \%$ by municipality, $30.6 \%$ by entrepreneurs, and only $6.4 \%$ agreed to let the responsibility of conducting the research to the professors. On the other hand, $30 \%$ of the company representatives interviewed consider that University is supposed to do the research, $0.0 \%$ professors, $40 \%$ municipality, and $30 \%$ of them share opinion that the research should be undertaken by companies.

\section{Figure 4.}

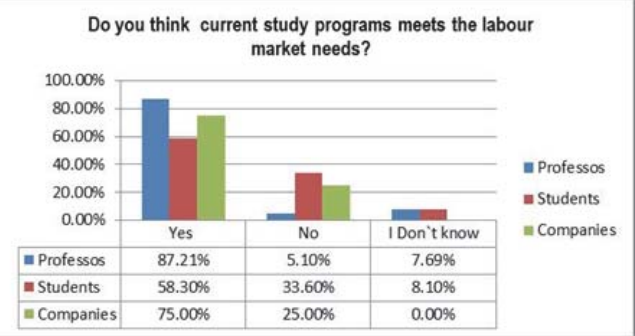

The questionnaire data, revealed form respondents answer to the question, do you consider that the current program at UHZ complements the needs of the labour market, are as follows: $87.2 \%$ of professors consider that program does complement the needs, $5.1 \%$ considers that it does not and 7.6\% stated that they don't know the answer. Whereas $58.3 \%$ of students believe that the current program complement the needs of the labour market, $33.6 \%$ don't think it does, and $8.1 \%$ of them doesn't have an opinion about the issue concerned. While $75 \%$ of the company representatives consider that the current program does complete market needs, the $25 \%$ of them believe that it doesn't. Based on a statistics student and company representatives in general have a positive attitude regarding the current program of $\mathrm{UHZ}$, however a great percentage shares a negative attitude. Comparing the students and company representatives, high number of professors, do believe that current program is appropriate for the labour market needs.

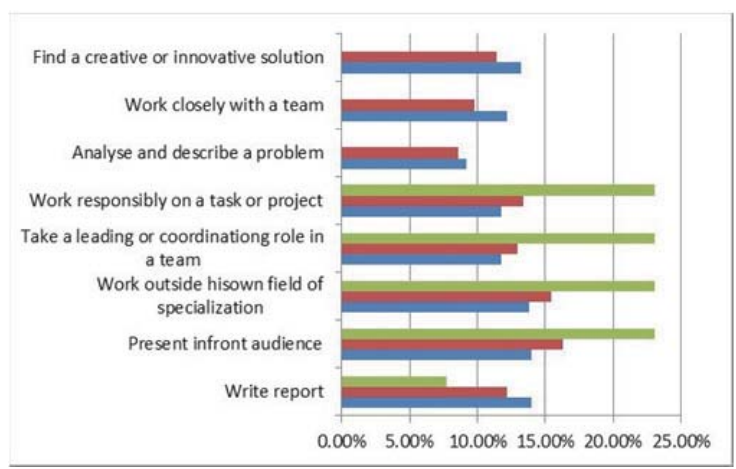

Figure 5. General competences (ability/skills) the graduates have.

The questionnaire data revealed from the question about the specific competences that students must acquire after graduating, answers evidence are shown to be more general. In this context, academic staff of UHZ, as the most relevant competencies that students should acquire considers to be the following: professional capacity development; creative solutions ability, analysing and describing. Whereas, some of the competences considered by students include; providing of knowledge about international trends in economy and political development, developing the ability of decision making; skills on scientific research; ability of working independently, and ability on writing the reports. Meantime, company representatives stressed on: professional and personal competences as well as ability of cooperation with labour market. Besides specific competences considered by participants in the research (as shown on the above figure) there aren't any other specific data considered. 


\section{Conclusions}

Management and decision-making process at public higher education institutions is basically regulated by law and approved by competent bodies as described by the statute which is approved by the Assembly of Kosovo. Thus, a study program undergo through the decision-making procedures which are defined by statute. The approach for decision making is Bottom-up decision making, which starts with the development and approval of study programs by the study commission within the academic unit, the study council of academic unit, then passes centrally in the university Senate, which consequently represents the end of this hierarchy for decision making within university. Then, the application for new study programs should be submitted to the Kosovo Accreditation Agency for accreditation, which is mandatory process. Referring to these procedures, and taking into consideration that they have characteristics of: (1) well-structuring proposals / problems and (2) clear criteria we conclude that for developing study programs, public universities uses programmed decision making type.

On the other hand, it is not used the same approach by private higher education institutions. The research results lead to another conclusion related to the procedures for curriculum development. The existence of procedures for review $/$ modification of curricula in private institutions, not necessarily contain "bureaucratic" procedure, which may can discourage competent bodies, respectively study commissions in the public institutions to initiate new study programs or revision of existing programs. While the decision in the curriculum development in private HEl's, in most cases, depending on the organization of the institution passes only through one decision making body that represents the highest academic body within an institution: Academic Council, Senate or by the management of the institution.

Development of the study programs at University "Haxhi Zeka" is considered by respondents to be an "act", rather than as a "process", that supposed to occur continuously, in accordance to the circumstances. As far as the question: who should initiate the new study programs development in the future, is concerned, a similar tendency has been noticed.

Over $97 \%$ of the three respondents groups agreed that before initiating any new studying program research on the market needs should be done, as to analyse the needs and requirements on specific field of study. However, there is no consensus on who is supposed to do such the research. Most of respondents stressed that such research should be done by University or municipality.

Additionally, the research determined that the current study programs at $\mathrm{UHZ}$ are developed mainly in consultation of some companies operating in Peja region, by guaranteeing the harmonization of the programs to the needs of the labour market. Regarding the competencies that students acquire, there are some uncertainties among the respondents about precise definition of the general and specific competences that students should possess when they graduates.

\section{Recommendations}

- Senate of the universities to initiate the development of new study programs.

- Researches before developing any study program, or modification / revision of current programs to be mandatory and set by institutional regulations.

- Funds for the market researches to be allocated by the institution.

- Involved staff on development of curricula to be stimulated: study commissions in the case of public institutions, and the team of teachers in curriculum development in private institutions, in order to increase the quality.

- Curricula to be developed in cooperation with other stakeholders: management, professors, students, and companies. This would increase the transparency of the process and will create possibilities to develop study programs in accordance to the requirements and needs of the labour market, that are comparable and competitive in the region and Europe.

- Documents that relate to the management of higher education institutions, public or private (e.g. statute) to be made public, so that interested parties have easy access to these documents.

- It is recommended the drafting of a catalogue of general and specific competences. This catalogue should serve to clearly determine each competence students will acquire during the studies.

- Establishment of "The Board of Advisors" that would be composed of all parties of interest, such as; companies, municipality, research institutions, professional associations, and independent experts. The board would continuously be consulted on the quality of current programs and for economic reasonableness of new programs development.

- UHZ should compile strategic partnership with 5 or 6 different companies, that would intensify the cooperation 
in many fields, as: consultation of developing new programs on skills and competences students have/should have in order to meet the requirements of the labor market; the professional practice commencement, for students on regular bases.

- Create an alumni network (of the graduates) on purpose of identification of the UHZ graduates recruitments possibilities. It proves the importance of access into labor market, based on the knowledge and competencies acquired.

\section{References}

Maguad B., Krone R. (2012). Managing for Quality in Higher Education.

Pownall I. (2012). Effective Management Decision Making, An introduction.

Grupi Kosovar për Promovimin e Procesit të Bolonjës. (2007). Politika të MASHT për integrim në Hapësirën Evropiane të Arsimit të Lartë.

Ligji mbi Arsimin e Lartë në Republikën e Kosovës. (2011). Nr. 04/L-037.

Ministria e Arsimit Shkencës dhe Teknologjisë. (2012). Strategjia e Zhvillimit të Arsimit të Lartë.

Höllinger S. (2010). Financing of Higher Education- Overall HE-Financing and State-to-HE-Institution-Funding, Institutional Funding Mechanisms, Student Financing, Proposals for Legislation.

Ministria e Arsimit, Shkencës dhe Teknologjisë e Kosovës. (2011). Plani strategjik i arsimit në Kosovë, 2011 - 2016.

Statutie of the University "Haxhi Zeka". (2011).

Statute of the University of Prishtina "Hasan Prishtina". (2011).

Statute of the University "Ukshin Hoti". (2010).

Agjensioni i Akreditimit të Kosovës. http://www.akreditimi-ks.org/new/index.php/about-us/mission.

lliria College: http://www.uiliria.org/uil.

Fama College: http://www.kolegjifama.eu/.

UBT College: http://www.ubt-uni.net.

AAB College: http://www.universitetiaab.com.

Universitety "Haxhi Zeka", (http://unhz.eu/index.php/universiteti/historiku). 